\title{
Profile Evaluation in Indonesia: The Encouragement of Educational Change Facing the Era of Digitalism
}

\section{Manurung, Paisal ${ }^{1 *}$, Aryni, Yen²}

${ }^{12}$ Doctor Program of Padang State University ${ }^{1,}$ English Education Study Program FKIP-UNA ${ }^{2}$

A R T I C L E I N F O

Article history:

Received 15 August

2019

Received in revised

Form 29 September

2019

Accepted 18 October

2019

Available online 29

November 2019

Keywords:

Education, Change,

Encouragement

\section{A B S T R A C T}

Education contribution to the formation of the style and quality of the future of human civilization can not be denied again. Education conventionally until the modern age was still believed to be a strategic location to expand the horizons and to provide the most valuable information about the meaning and purposing of life as the norm was taken. It needed that were essential to face the challenges of the changes in the future to create individuals, communities, and nations. While education digitalism was a very effective system to improve the quality of human life in all aspects of human life, education presented conscious efforts. Encouragement of education not only in preparing personnel professional teachers in their field but also encouraged prepared proteges facing to change towards conventional for digitalism. A fundamental change in the framework of preparing students was: change's ideology, self-control, futuristic effect, meaning in life. 


\section{Introduction}

The worldview of current educational figures today, are perspective related education system is in operation, it very makes everyone instantly amazed. It can Improve the quality of education in universities is determined by lecturers, curriculum, facilities and adequate infrastructure and all that takes a learning process (Pujawan 2018). A theory mature in maximizing the educational process, curriculum, facilities, teaching methods, to the evaluation system. However, because of the contribution of education in preparing young people are still very, very powerful far what to expect. Moreover, regarding the evaluation of learning, the evaluation of educators, facilities and infrastructure that channels the related measuring the success or failure of students to absorb, understand, prepare, and intake given by educators in the learning process. Evaluation is crucial in providing follow-up to the development, achievement, independence, problem-solving learners, both in the cognitive, affective, or psychomotor.

If we look at the reality, the sentence can be justified, which is a high value in the report card or diploma that can determine the admissibility of the owner of the value in applying for a job. So it is not a strange thing when in school or college, learners further pursue high academic value and ignore a good process. Finally, pragmatism becomes the inevitable choice to achieve the desired future. This condition portrays to us that the concept of a better life becomes one meaning data of the teaching and learning process. Supposedly with this evaluation system, more educators can direct learners achieve maximum learning results, both from the aspect of cognitive, affective, and psychomotor. And this point, we can take some points like the real statement that learning processes will be active and enjoy, if the teacher and all parts in teaching and learning understand the students' condition (Ornstein dan Levine 2008).

In maximizing the change in the ideological impetus of change, and others including the encouragement of learning indeed not easy, but not impossible it can be executed. Chinese philosophers say, there are no bad students, only bad teachers. At first glance this philosopher's words to discredit the position of an educator, but on the other hand need to ponder these words together, even a challenge for educators or students in maximizing their role and function as second parents (Yahaya et al. 2008). This happens because educators have seen their future in effect futuristic glass eye, but it is not delivered in glasses learners, thus giving black people to the educational process of our comments today.

Today proved that modernization of traditional culture has shifted towards the modern materialistic culture (Ochoa Delarriva dan Basabe 2015). The exploitation of natural resources by utilizing advanced technology produces material wealth is uneven. As a result of human greed, whether abundant or deficient competing so can not enjoy prosperity as expected. Just as Nietzsche predicted in 1887 that in the modern age and the degree of equality among people and nations is nonsense; that there is a competition or a "war". Modern life makes people increasingly self-centered so that the exploitation of natural resources with modern technology is not able to increase the prosperity evenly but instead created a gap; the strong stronger weak weaker (Psikologi 2015).

A lot of things that can be done by educators in implementing what is called the impetus of change. However, the problem is 1) Education is not oriented to the unity of the nation, 2) Prioritize the content or the content rather than learning activities, 3) Values are preferred, from the learning process, 4) Low desire of the government and the state in managing the education well, 5 ) The system of socio-economic ideology so real insight. Of the various aspects of the problem, yet important aspect of change in education during this digitalism era is self-control self-Controlling and meaning in life.

The objective is so important in addressing the phenomenon is the case today, as steps futuristic effects that have been present in all aspects of the needs, abilities, skills, human needs. So the purpose of a boost it is creating:1) Ideology about the changes, 2) Self-control, 3) Futuristic effect, 4) The concept of a better life. While the impetus given destination will continue to evolve over the sides of the life to come, like the media or the means to save the nation from a setback for science and setbacks in behavior, attitude, and actions in making decisions. Thus, the problems in the education body will continue to be minimized by the state itself.

\section{Methods}

The method used in this writing is to use a desk review or known library research. The desk review conducted looked for several books and journals that were relevant to the problem presented. Then in collecting data, the writer does several stages, including 1) Finding material for books or journals that are relevant to the background of the problem in the library and online journals. 2) Reviewing books and journals that have been collected. 3) Discuss and discuss several books and journals with lecturers and friends. 4) Review input and opinions based on discussions and presentations of books and journals. 5) Doing the content and information corrections on the writing that was done. 6) Publication. 


\section{Result And Discussion}

\section{Human in Education}

The service education process in pluralistic interchanges conditions (between subjects with the environment natural, social and cultural) is determined by the human aspect. Therefore, the position of man as a sub- jack in society, even in the universe, providing big responsibility consequences for humans. Humans carry out the mandate to foster community, preserve the natural environment together. Even the man primarily responsible for the dignity of his humanity (human dignity). Nature preserves the environment together. Even the man primarily responsible for the dignity of his humanity (human dignity). Nature preserves the environment together. Even the man primarily responsible for the dignity of his humanity (human dignity).

(Prayitno. 2009) history of human attempts to understand himself, his personality, had been there since there is science. Psychiatry (psychology) early form of psychology metaphysics is one such effort. Investigate human personality deepens, more and more problems arise, the more secrets that demand answers. Human beings are unique mysterious and secretive.

Human beings think to ask, who or what am I? Human as subjects make themselves (as individuals and as a whole), and if an object that requires understanding, knowledge or understanding. "Know thyself!" Are the words that remain classical ideal meaning, are particularly to be pedagogical, in addition to valuable philosophical. So far, man is still not convinced that he had identified himself. Even deeper he plumbed and understand his personality, the more difficult it understands its identity.

This dynamic principle is the essence of human nature, evolving, growing and leading the integrity of his personality (Prayitno, 2010). Similarly, the human sense about a person, about his personality, always evolving. That is why it is said: "not know it was love". Even the "love that grows out of recognition". That is, the more we know, the more we understand his personality.

\section{Era Digitalisme and Futuristic}

The digital word is a term used by the public to termed as a form of human activity that can be represented by the machine. In concept in the realm of education in the digital age is that education must integrate ICT into all subjects. With the development of the digital era, education allows students to gain knowledge abound as well as quick and easy. The problem faced is globalization, economic growth, international competition, environmental issues, culture, and politics. Futurism history of French, or English future, future both of which means "the future" is a science that studies the future. In addition, this stream is a stream of avant-garde art or before the time, especially in 1909.

This is especially the most powerful flow that appeared in Italy, although there are also followers in Great Britain and Russia. Manifesto of Futurism (Italian: " Manifesto del Futurismo ", English: manifesto of futurism) is a manifesto written by an Italian poet Filippo Tommaso Marinetti, in 1909. In this manifesto, Marinetti conveys an artistic philosophy, Futurism, who reject the past, celebrated speed, machinery, violence, youth, as well as industry. The manifesto also calls on modernization and cultural rejuvenation in Italy (Indonesia 2015).

Futurism is an art form in Italy founded by Filippo Marinetti in 1908. The movement was inspired by the life has changed since the invention of the machine that produces elements of movement and speed are very influential to human life in the early 20th century. Typography in Futurism developed into a medium of expression in the design, not the meaning but also its shape, visualized poetry forms that use typography as an expression of the feelings that support the work of the poem(حسنى،حما 1385),

\section{Democracy and Socio-Economic}

The function of education in a democracy is a series of tasks or of the mission and must be carried by education (Siswoyo, Dwi, et al, 2011). Task or mission of education that can be fixed on the man who is teaching as well as to the society in which she lived nation. For herself, education serves to prepare to become a whole man, so that he can perform his duties well and can live decently as human beings (Kivisto 2018). The function of education to the public at least two major parts, namely the function evaluation and directive function performed by preserving social order and values that exist in society, whereas the directive functions performed by education as an agent of social change, so as to anticipate the future.Education held in democratic and non-discriminatory justice and human rights, religious values, cultural values, and the diversity of the nation (Campbell 2016).

From the description of the articles can be concluded that Indonesian national education Pancasila, the national education goals also reflect the realization of the values of Pancasila in protégé as Indonesian citizens. There needs to be good character development in the educational process democracy, among others: 
1. Discipline yourself needs to be instilled in the student/student, faculty/teachers, coaches, counselors, and all the components involved in the learning process.

2. Compassion moved flavors that accompanied compassion can get through stories-stories or proverbs that are useful as optimally as possible.

3. Responsibility who are not responsible is a characteristic of the immature other people, otherwise, there is a sense of responsibility, we really help to mature. Children need to be trained tasks, school assignments and work together voluntarily where necessary.

4. Friendship is stories-stories that convey the student /students' friendship good is a moral paradigm for all human relationships. We Harusmengajarkan to students how to choose a friend (friend) was good. Demands a honesty, openness, loyal, self-sacrifice, that this all is very potential to help the realization of moral maturity and honesty steady.

5. Work is the first step in doing something is to learn how to do something. In this case, it needs to be an act that all the work is good and noble, how to appreciate the work, how to work together, to give encouragement and appreciation of the efforts, working full design jovial, accompanied by proving examples carefully and thoroughly.

6. Bravery and courage are this heart that needs to be instilled in the face of feelings of fear, the nature of nervous hesitation, falter, and other properties that often interfere. Children need to be encouraged and raised the motivation to practice with intelligence.

7. Perseverance is how to encourage students/students in order to persevere and continue to implement efforts to increase courage and perseverance. They need to be guided and directed as well as give positive examples, by promoting the principle of "Tut Wuri Handayani".

8. Honesty makes learners need in students being personally honest, to do a real, pure and can be believed. Honesty embodied or expressed in the form of respect to themselves and to others. This needs to be trained and learned, which is essentially a lifetime, in order to become a man of integrity and a willingness noble.

9. Loyalty correlates with kinship, friendship, religious affiliation, professional life, and the other. It can be changed and developed towards a better and glorious one.

10. Belief gets God Almighty is a very important dimension is the moral source. Assurance million is a source of discipline and strength that is very meaningful in human life. It can help the stability of the social and moral development of individuals and society. Therefore it needs to be owned by the children as early as possible in accordance with their developmental stages.

Economic or material is the only thing that matters and became the benchmark of human life, not a thought or idea. Marx's attitude that puts every interest only as part of the economic interest is considered excessive and illogical. Marx believed, directly or indirectly, political power is a tool to the interest of economic power function only. The absence of ideas or ideals and attitudes to laud the material that makes Marx widely condemned (Wei dan Peters 2019). The failure of the education system is associated with governance is not adequate for 'monitoring is not perfect and weak accountability in the public system that can be resolved by the competitive strength of school choice or by external monitoring more closely the results of education, even if this may lead to attempts signaling that it is the schools and teachers(Kivisto 2018), (Wei and Peters 2019),

Furthermore, in the neoliberal and socio-economic there are some things that are important in the education of the neoliberal approach, education has three functions: first and foremost, education is a catalyst for economic growth in a society with equal opportunity, thus requiring monitoring individual performance; Secondly, education is a separate business sector; and third, education is the sites 'failures' that need to be changed to deal with the crisis, be it economic, or political nature (Kivisto 2018).

Meanwhile the student's problem towards of the socio economic will affect to their conditions, it is said (Psikologi 2015) In some problems experienced by individuals are disrupting their daily lives.

The existing problems will disrupt the effective daily life (KES) so that the disrupted effective effective daily life, namely the problematic life (Prayitno 2005). Furthermore Prayitno (2005) states that problematic living conditions are characterized as follows: a threatened feeling of security, increasingly acute and more dissolving themselves in the darkness and solitude, competence that is stuck and never aroused which will further plunge the individual into an uncultured state and do nothing, the confined aspirations will further undermine the sky above him, a withering spirit will prevent him from doing anything meaningful, opportunities that are actually open to him will be wasted in vain.

\section{Learning Theory of Contructivisme}

Constructivism learning theory considered a theory of learning that is relevant in the process Study abroad and learning in the digitalism era. This theory emphasizes the students as interaction with objects, 
phenomena and their environmental experience(P. Pannen, Dina Mustafa, and Mustika Sekarwinahyu 2001). Students formed a scheme, categories, concepts, and structures necessary knowledge to knowledge. Knowledge is not about things apart from the observer, but a human creation that is constructed from experience or the world is going through. The formation process is running continuously, and each time a reorganization or reconstruction for their new experience (P. Pannen, Dina Mustafa, and Mustika Sekarwinahyu 2001).

Constructivism becomes a popular approach and thrives in the current teaching practices. It could not be separated from the underlying theories. The main theory of this approach initiated by psychologists who considered large. Not only are many advantages when implementing a constructivist approach in the learning process in the classroom, but there are dilemmas in practice approach this (H. Dadang Supardan 2016), In other words, constructivism terminology "constructivism" can be metaphoric as the ocean, as far as we looked at did not seem territorial. It is limit if the term is used by philosophers, curriculum designers, psychologists, educators and others(H. Dadang Supardan 2016),

The basic principle underlying the philosophy of constructivism is that all knowledge is constructed (built) and not perceived directly by the senses (smell, touch, hearing, touch, and etc.) as well as the assumption of the realists in general. Moreover there is no single constructivist theory, but most of the constructivists have indeed the same two main ideas; (1) an active learner in constructing his own knowledge, and; (2) social interaction is an important aspect of construction of knowledge (Bruning, Scraw, Norby, \& Ronning, 2004).

Future human characteristics are expected in the context of building human resources are people who have sensitivity, independence, responsibility for risk in decision making, developing all aspects of potential through continuous learning process to find themselves, the process to learn to be. To achieve this goal constructivistic learning theory is chosen. It is because compared to other learning theories, this theory can anticipate a shift from education that it emphasizes cognitive aspects to aspects of human potential as a whole (Sumarsih 2009). So it can be realized, lecturers must take the initiative to organize the environment that provides optimal opportunity for learning to occur, but it is what ultimately determines the realization of learning symptoms is the student's own learning intention. The constructivist paradigm views students as individuals who have initial abilities before learning the new knowledge.

Assessment of student learning processes is an integral part of learning, this is conducted through lecturer observation of student work through exhibitions of student works, and portfolios. There are several constructivist learning strategies, namely active learning, independent learning, cooperative and collaborative learning, generative learning, and cognitive learning models all of which can be applied (Sumarsih 2009).

\section{Aspects of Encouragement Changes}

1) Ideology about Changes

The term is derived from the idea ideology, which means ideas, concepts, basic understanding, ideals; and logos meaning science. Ideology etymologically means the science of ideas (the science of ideas), or the doctrine of basic understanding(Agus 2016), In Big Indonesian Dictionary, ideology is defined as a collection of concepts taken as applying for the opinion gives direction and purpose for survival. Ideology also is interpreted as a way of thinking of a person or a group. Ideology can mean understanding, theories, and goals, which is a political and social program. In this sense, we caught some important components in an ideology, a system, direction, purpose, way of thinking, programs, social and political.

The history of the concept of ideology can be traced long before the term is used by Destutt de Tracy at the end of the eighteenth century. Tracy called the ideology as the science of ideas, which is a program that is expected to bring institutional change for the people of France. However, Napoleon denounced the term ideology that he considered a mere illusion, which has no practical meaning. Such a thing is only wishful thinking that will not be found in the fact(Agus 2016).

Every man for life must be changed. Changes can be interesting and less interesting changes. There are changes whose influence is limited and it is also extensive and no changes are slow or fast. There is no society that is stopped at a certain point of all time. Such changes may include social values, social norms, patterns of behavior and the community or other institutions. By William F. Oqbun argues, the scope of social change includes elements of culture, both material and nonmaterial (Agus 2016),

\section{2) Temperance (Self-Control)}

Self-control is a potential that can be developed and used people during the processes of life, including in the face of conditions contained in environments are nearby. Experts argue that self-control 
can be used as a preventive intervention in addition to reducing the effects of the negative psychological environment(Bint Ida Umaya 2017), Emotional maturity should be reached at the end of adolescence, but of emotional maturity in the late teens to be different from the emotional maturity in older individuals. Increasing the age of the individual, the emotions are expected to be more mature than the younger individuals(Binti Ida Umaya 2017), In all aspects of life, the individual is in need of good self-control. By having a good self-control individual can steer, estimate and predict the impact of the behavior they are doing. Self-control (self-control) is defined as "the process of setting the physical, psychological, and behavior, in other words, a series of processes that formed her own(Fadillah 2013).

\section{3) Futuristic Securities}

Futuristic is nature or relating to the future. Futuristic is a loan word from English, futuristic. The words used to express something new, modern, and had never been there before (Kivisto 2018), Thus, the meaning of futuristic effect is a situation where students in the context of the conditions the state should be simplified by educators to students in the classroom and outside the classroom (Indonesia 2015), Futuristic look that conditions students must be directed and guided to the things they were able to make it part of the experience of the learning activities in the renewable part. This is very important in preparing students in structuring effect of the negative influence from futuristic (Fadillah 2013), The most important part in determining the readiness of educators in preparing students in this futuristic negative impact are:

a) The provision of good facilities and infrastructures.

b) The educator serves as a medium of learning.

c) The educator is an educational psychologist.

d) The students are user media, not as a "connoisseur" media.

e) The students are taught the importance of knowing the media or digitizing correctly and well.

4) Better Living Concepts

The concept of a better life or meaning in life is an action, thoughts, feelings and belief orientation but to prosper. But on the other hand that the concept of a better life also means that how a person is overcome challenges and maximize the life of the unique proteins (Fridayanti 2013). In such conditions it is very important we give a good understanding to the students of the importance of the concept of a better life or we interpret as meaning in life in all their activities.

\section{Conclussion}

Berdasarkan Conclusions can draw from this discussion are:

1. Education is not oriented to the integrity of the nation which is characterized by the absence of an effective impetus or step towards the significance of education towards an era of digitalization.

2. Learning activities or learning experiences in the era of digitalization is more propriety emotion, while the contents or content-oriented towards analytical skills and enrichment.

3. The learning process within the framework of democratic education, with emphasis on the meaning of democracy education 10 things are discipline, compassion, responsibility, friendship, work, perseverance, honesty, loyalty, and the assurance. Thus, it should be applied to all learning activities.

4. The low desire of the government and the state in managing a good education. It was a sign of changes in the system of democratic governance that characterized the socio-economic make education as an educational corporation. Causing students squeezed to meet business creation prolonged.

5. The best encouragement in the face of this era is to the principle of digitalism to the activity or learning experience in the form of:) Ideology of change, b) Temperance, c) Futuristic effect, d) The concept of a better life.

The advice can be given the government, professional teachers, stakeholders, and educators should be involved to encourage changes in education in the era of digitalization that we now feel. Characteristic digitalism which cause we need to do a faster impulse to the process of teaching and learning. The impetus of this change can occur if all elements of government elements as the decision-maker view and analyze these changes, and to society as monitors or controllers urge those changes. Thus, boost educational change in the system of teaching and learning will be realized. 


\section{Reference}

Agus, A Aco. 2016. "RELEVANSI PANCASILA SEBAGAI IDEOLOGI TERBUKA DI ERA REFORMASI A. Aco Agus Fakultas Ilmu Sosial, Universitas Negeri Makassar." Jurnal Office 2(2): 229-38. http://ojs.unm.ac.id/jo/article/download/2958/1608.

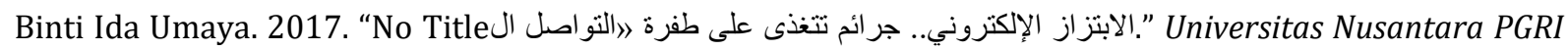
Kediri 01: 1-7. http://www.albayan.ae.

Campbell, James. 2016. "Democracy and Education: Reconstruction of and through Education." Educational Theory 66(1-2): 39-53.

Fadillah, Galih Fajar. 2013. "Upaya meningkatkan pengendalian diri penerima manfaat melalui layanan bimbingan kelompok di balai rehabilitasi mandiri semarang."

Fridayanti, Fridayanti. 2013. "Pemaknaan Hidup (Meaning in Life) Dalam Kajian Psikologi." Psikologika: Jurnal Pemikiran dan Penelitian Psikologi 18(2).

H. Dadang Supardan. 2016. "Teori dan Praktik Pendekatan Konstruktivisme dalam Pembelajaran." Edunomic 4(1): 1-12.

Indonesia, Pendidikan D I. 2015. “Leksi metafisika pancasila).” V(2): 832-42.

Kivisto, Hanna. 2018. "Capital as power and the corporatisation of education." Critical Studies in Education 59(3): 313-29.

Ochoa Delarriva, Ornella, dan Enrique Alejandro Basabe. 2015. "Reading Logs and Literature Teaching Models in English Language Teacher Education." How 22(2): 37-53.

Ornstein, Allan C., dan Daniel U. Levine. 2008. Foundations of Education (10th Edition).

P. Pannen, Dina Mustafa, dan Mustika Sekarwinahyu. 2001. "Konstruktivisme Dalam Pembelajaran." Konstruktivisme Dalam Pembelajaran: 1-25.

Psikologi, Buletin. 2015. “Kajian Psikologis Kebermaknaan Hidup.” Buletin Psikologi 14(2): 115-35.

Pujawan, Kadek Agus Hendra. 2018. "the Development of Interactive Multimedia With Drill and Practice Model on Multimedia Ii (Two Dimention Animation) Course in Politeknik Ganesha Guru." Journal of Education Research and Evaluation 2(1): 22-27.

Sumarsih, Sumarsih. 2009. "Implementasi Teori Pembelajaran Konstruktivistik Dalam Pembelajaran Mata Kuliah Dasar-Dasar Bisnis." Jurnal Pendidikan Akuntansi Indonesia 8(1): 54-62.

Wei, Zhao, dan Michael A. Peters. 2019. “Intelligent capitalism' and the disappearance of labour: Whitherto education?" Educational Philosophy and Theory 51(8): 757-66. https://doi.org/10.1080/00131857.2018.1519775.

Yahaya, Azizi et al. 2008. "Psikologi Pendidikan." : 324.1385. "No Title فرهنى و رسانه هاى نوين." http://www.ghbook.ir/index.php?name= فرهنى نوين emid=218\&lang=fa\&tmpl=component. 